\title{
Migrant precarity and future challenges to labour standards in Sweden
}

Charles Woolfson, Judy Fudge and Christer Thörnqvist

\section{Linköping University Post Print}

\section{Tweet}

N.B.: When citing this work, cite the original article.

Original Publication:

Charles Woolfson, Judy Fudge and Christer Thörnqvist, Migrant precarity and future challenges to labour standards in Sweden, 2014, Economic and Industrial Democracy, (35), 4, 695-715.

http://dx.doi.org/10.1177/0143831X13494249

Copyright: SAGE Publications (UK and US)

http://www.uk.sagepub.com/home.nav

Postprint available at: Linköping University Electronic Press

http://urn.kb.se/resolve?urn=urn:nbn:se:liu:diva-107378 


\title{
Migrant precarity and future challenges to labour standards in Sweden
}

\author{
Charles Woolfson \\ Linköping University, Sweden \\ Judy Fudge \\ University of Kent, UK \\ Christer Thörnqvist \\ Linköping University, Sweden
}

\begin{abstract}
Fears of a 'race to the bottom' in labour standards may have been overstated. Nevertheless, using Sweden as a case study, it is argued that the diminished capacity of trade unions to defend labour standards following the Laval judgment of the European Court of Justice, together with a decline in trade union density, a limited remit of enforcement authorities and recent changes to the Swedish labour migration regime, may have detrimental impacts on labour standards, particularly in low-skill low-wage occupations. In combination, these developments are creating new spaces for migrant precariousness within the context of a formerly well-regulated Swedish labour market model.
\end{abstract}

Keywords Posted workers, Laval case, migrant labour, 2008 Swedish migration reform, labour standards, Swedish model.

\section{Corresponding author}

Charles Woolfson, Institute for Research on Migration, Ethnicity and Society (REMESO), Linköping University, Campus Norrköping, Sweden. Email: charles.woolfson@liu.se Tel: +46(0)722500787. 


\section{INTRODUCTION}

This article develops an analysis of the contemporary challenges to labour standards in Sweden. Sweden offers an interesting case study as one of the Nordic/Scandinavian countries that historically has had very high levels of trade union membership and coregulation by the social partners, largely free of government interference. This is now changing, as Sweden's welfarist social model based on egalitarianism and social inclusiveness accommodates a more neo-liberal political, economic and social formation as preconditions for global competitiveness (Schierup and Ålund, 2011; The Economist, 2013). Currently, Sweden ranks fourth in the World Economic Forum's Global Competitiveness Index of 144 countries (Schwab, 2012: 13).

The article addresses the question of whether there is a 'race to the bottom' as a consequence of the Laval judgment of the European Court of Justice, limiting the ability of trade unions to prevent 'wage dumping' through industrial action (Krings, 2009; Woolfson et al., 2010; Lindstrom, 2010; Krings et al., 2011). It is suggested that longer-term changes in the national industrial relations model and a reform of Swedish migration regulation in 2008 may be equally salient factors in undermining labour standards. In respect of the impacts of changes to the migration regime, the article attempts to contribute to a wider debate concerning the interplay of market regulation and 'open' liberal migration regimes (Wright, 2012). It is argued that a 'race to the bottom', at least in the sense of an accelerated competitive downwards spiral of deteriorated wages and conditions, may not have yet begun in the Swedish context. Nevertheless, despite persistent strengths of the Swedish model, complacency concerning the robustness of labour standards entrenched in collective agreements would appear to be ill-founded. There is the potential emergence of an unregulated secondary labour market with significantly lower wages and poorer working conditions for migrant workers, which is facilitated by weak labour inspection and 
enforcement, particularly in the sectors to which low-skill migrants have been recruited under Sweden's new migration regime. Compounding all of the above is a longer-term overall decline in trade union density. Union density declined from a peak of $85 \%$ in 1995 to $71 \%$ by 2012 (LO, 2012a: 7; Kjellberg, 2012: 50-52). While by international standards union membership remains relatively high, this disguises differential sectoral rates of decline, so that even in areas of former core union strength membership reductions of significant magnitude have occurred. Thus, during the same seventeen year period, union density among blue-collar workers had fallen by more than one fifth, from $88 \%$ to $68 \%$ (LO, 2012a: 15). Such reductions in union density, in turn, are creating new spaces for precarity to emerge not only in construction, but also in private services and other occupations increasingly reliant on recruitment of low-skill and low-wage labour migrants.

We proceed as follows: First, the main contours of the Laval judgment of the European Court are reviewed and its implications for collective bargaining and standard-setting in Sweden are discussed. Against this background, qualitative evidence of exploitation of migrant labour is presented. Second, the implications of the major reform of the Swedish labour migration regulations are assessed utilising a detailed empirical review of this regime by OECD (2011). Third, the responses of the regulatory authorities and of trade unions to perceived challenges in labour market regulation and the maintenance of labour standards are discussed. The article concludes by asking whether the 'open' liberal character of the Swedish migration regime is succeeding in its stated objectives, or whether, in the context of a weakening industrial relations model, there is the possible emergence of a segmented and 'precarious' migrant labour force in Sweden today that is beyond the protective reach of its labour market model. 


\section{The Posted Workers Directive and Laval}

In the debate over labour standards, the Laval (Case C-341/05 [2007] ECR I-11767) of the European Court of Justice (ECJ) (since renamed the Court of Justice of the European Union), has become emblematic of a wider shift in the balance of power between labour and capital in favour of free movement of services within the European single market. It is also seen as marking an alteration in the priorities of the broader European project towards more market-driven ends at the expense of labour rights (Davesne, 2009; Dølvik and Visser, 2009; Kilpatrick, 2011; Bosch, 2012). For European trade unions, the Laval judgment and a related series of European Court of Justice decisions resonate with the seemingly relentless pressure by capital on labour's capacity to defend previously established standards such as those established through the Posted Workers' Directive (ETUC, 2007; Engblom, 2012). The Laval judgment, in this view, represents an important judicial punctuation point in an evolving political and legal discourse over the narrowing of collective labour rights (Eklund, 2006; Ashiagbor, 2009; Fudge, 2011; Asteriti, 2012).

The broad outlines of the Laval case are well-known. In June 2004, the Latvian construction company Laval un Partneri started contract work to refurbish a school in the Vaxholm municipality outside Stockholm. The work was carried out by Latvian building workers posted to Sweden, that is, providing services in a host state while remaining in the employ of a Latvian 'home state company', Laval un Partneri. The building workers' union, Byggnads, urged Laval to settle a Swedish collective agreement providing comparable wages and conditions to those of Swedish workers in the Stockholm area. The company however refused to sign any such undertaking, which resulted in a blockade, starting on 2 November 2004. In April 2005, the case was brought before the European Court of Justice, as the Swedish Labour Court (Arbetsdomstolen) which had first heard the dispute, 
sought clarification as to whether the union industrial action contradicted certain aspects of EC law regarding freedom of services and non-discrimination.

On 18 December 2007, the ECJ ruled that the blockade represented a restriction on freedom to provide services as defined by the EC Treaty. The Court argued that such actions could be justified in cases where the public interest of protecting workers prevailed. However, this was not the case with respect to Laval. In short, the ECJ held that the trade unions were precluded from attempting to use collective action against a provider of services established in another Member State to force the provider to accede to rates of pay or other core conditions superior to those indicated in the relevant national legislation by which the Directive was transposed. The Court held that Sweden's transposition of the Directive did not contain sufficiently clear guidelines for a foreign service-provider to assess what those core minimum conditions might be. In the light of the ECJ judgment, the Swedish Labour Court returned to the Laval case and applied the interpretation handed down by the ECJ in a final determination on 2 December 2009. The Court followed the ECJ ruling and declared the blockade illegal; consequently the trade unions (the construction union and the electricians union, which took sympathetic action) were required to pay damages. Lex Laval, which subsequently transposed the ECJ judgement into Swedish law, came into force in April 2010 (Government Bill 2009/10: 48, bet. 2009/10: AU5, Comm., 2009/10: 211). This legislation amends the existing Swedish act on the posting of workers and narrowly restricts the rights of trade unions to take action against a foreign employer (Malmberg, 2010: 11).

A peculiarity that differentiates Sweden from most EU countries should be highlighted. The series of ECJ rulings regarding posted workers preclude trade unions from any attempt to force a company from another EU State to impose more favourable conditions than those 
resulting from relevant national legislative provisions. In particular, the Court addressed wages, but also other forms of labour conditions were encompassed within its ruling. This interpretation of the Posted Workers Directive might be a less of a problem for trade unions in EU countries with well-developed national minimum wage systems (although enforcement is still critical). But in Sweden, wage-setting is up to the social partners, largely without interference from government or legislation, in the so-called autonomous collective bargaining model. Thus, nation-wide industry agreements set the framework for shop-floor remuneration, although there is still room for workplace solutions such as bonus systems, piecework rates or fringe benefits. Industry-wide, national collective bargaining is an important feature in most EU states; yet the main reason why the Swedish agreements have been so strong and encompassing is found in the links between the industry level and the shop-floor. Unlike in other EU countries, there are no works councils in Sweden to provide alternative bargaining mechanisms. Instead firm- or shop-floor level negotiations over wages and working conditions are handled solely by a local trade union branch. As a result, employees even in small Swedish firms can always get support from trade union ombudsmen in pay negotiations as well as in conflicts over other matters. This mechanism has proved particularly beneficial to employees when it comes to pay setting, since wages are therefore at approximately the same level in smaller companies as in large ones, something that is rather unique in the EU (Andersson and Thörnqvist, 2007). In contrast to the majority of countries in the EU, there is no legislation establishing a minimum wage that provides a clear baseline for collective bargaining negotiations. Minimum wages are set solely by the collective bargaining process, but the outcome of these negotiations cannot be extended erga omnes, that is, to encompass companies not formally bound by the agreement, which is a common device in many countries to protect wages, particularly in low-pay sectors (Schulten, 2006: 12-14). 
Although the outcome of collective bargaining rounds cannot be automatically extended to encompass all companies in the industry, the Swedish trade unions can still influence the wages even in companies without trade union members. If the company is affiliated with an employers' association, the trade union can legally force the company to settle a firmlevel agreement in line with the industry-wide one. If the company is not a member of any employers' organisation, the trade union still has the right to take industrial action to force the employer to either apply for membership to the relevant employers' association or to sign the most relevant existing agreement. Most importantly, if there is no existing local/firm level collective agreement, the union and the individual employer can settle an 'affiliated' agreement that for the most part is a blueprint of the industry-wide agreement, sometimes slightly adapted to the workplace concerned, an adaptation usually based on local agreements in comparable firms in the same environment. The Swedish term is 'hängavtal', a term that is best translated as 'overarching agreement', that is, an industry agreement that spreads out over many small firms and workplaces. If the employer for some reason refuses to sign such an agreement, the trade union can call a strike of its members at the workplace, and, if there are no union members, it can put the firm under a blockade or a boycott. In the latter case, the main purpose of the action is to avoid 'wage dumping'; that is, to prevent non-unionized workers from accepting wages lower than union members in comparable companies and, at the same time, to prevent employers from discouraging employees from becoming trade unions members by offering better conditions if they remain non-unionized (Thörnqvist, 2011).

What is described in brief here is how the industrial relations system in Sweden worked during the heyday of the Swedish labour market model. Legally, the principles and functioning are still the same, but the system today is under pressure. On the one hand, high trade union density is not absolutely necessary for the model to operate because of 
the possibility to avoid wage dumping through affiliated agreements. But on the other, when union membership declines, so does the number of full-time trade union ombudsmen, who effectively enforce wage rates and related benefits. Swedish overall union density, already declining, has fallen significantly further since 2006, when new rules for contributions to the unemployment insurance funds that tied dues to unemployment benefits were introduced by the new centre-right government. This change to how unemployment insurance was funded accelerated longer-term trends of decline in trade union recruitment (especially of younger workers) that had already impacted upon the Swedish social model (Anxo and Niklasson 2006; The Economist (2012). The large increase in union dues for some unions, especially those in the private sector to cover unemployment insurance contributions, created incentives for workers not to join unions.

Since there are no works councils, workplaces without contact with trade union ombudsmen become workplaces without employee representation and influence. Most crucial, though, is that the system was developed before there were any 'posted workers', at least not in the legal sense, working in the Swedish labour market. By circumscribing the right of national trade unions to undertake collective action to enforce domestic terms and conditions on foreign employers sending workers to Sweden, the ECJ in Laval highlighted the soft underbelly of the Swedish model of autonomous collective bargaining pay formation.

Sweden was one of the three older EU member states along with UK and Ireland that imposed no temporary restrictions on the free movement of the eight newer EU member state nationals from 2004. However, the proportion of Central and Eastern European migrants who arrived in the country has been much lower than elsewhere, for example, in UK and Ireland. The tighter labour market regulation in Sweden, together with the 
significant barriers of language, has, we suggest, made it, until recently, less attractive for employers to recruit posted workers. According to estimates, which are acknowledged to be 'very imprecise', the number of posted workers has been at around 1,050 workers at any one time in the building sector, with about 280 workers in the electricians sector and around 900 in the metalworking sector (Eironline, 2010). While numerically, the numbers of officially posted workers have not been large, trade unions are concerned that the negative impact on terms and conditions of work in the construction sector has been significant (LO, 2012). Thus, while Swedish trade unions still possess considerable strength even post-Laval (MacKenzie et al., 2010), this does not mean an absence of pressure on wages and conditions, especially from the presence of 'bogus' self-employed workers or those with 'false' or 'double' collective agreements (created for the benefit of Swedish trade unions but in reality not applied) (Thörnquist, 2011: 121ff).

Yet there is surprisingly little detailed research on the impact of Laval on the Swedish labour market; an exception being a report by the trade union confederation (LO) on posted workers (Jonsson et al., 2011). This investigation of terms and conditions for foreign workers in major infrastructure projects suggested that foreign workers received between $55 \%$ and $80 \%$ of the rate per hour of an equivalent Swedish worker. What created substantial pay differences were (illegal) deductions for travel, housing and tax from both gross and net wages (Jonsson et al., 2011). At all three major infrastructure projects examined by LO, accident rates were approximately two to three times the norm for large-scale construction projects (Jonsson et al., 2011: 26). One factor in these anomalous accident rates may be the large amounts of overtime, often unpaid, which Polish workers reported (in excess of 200 hours per month) (Jonsson et al., 2010: 26). The trade union study, based on an analysis of contracting arrangements, suggests that the major client employers 'actively worked to hold down costs...by consciously engaging 
contractors who keep down prices by using foreign labour' (Jonsson et al., 2011: 16). Reports in the media also suggest that one of the biggest client companies had employed the same Polish staffing agencies for jobs in Sweden since 2003. To avoid tax and social cost obligations imposed on 'permanent establishments' in Sweden, the Polish firms were dissolved every year, just to emerge again a few days later under a new name, but with the same main owners or their relatives (Färnbo, 2010; Dahlkvist et al., 2010). Moreover, it would appear that the workforces were rotated every six months in order to avoid payment of Swedish income tax and social insurance obligations (Jonsson et al., 2011: 4). In smaller scale house-building and renovation work, disparities between the collective agreement rates and wages and benefits for temporary foreign workers, either subcontracted via an agency or supposedly 'self-employed', are likely to be even larger, especially for those working in the so-called grey or 'unofficial' economy. Here tax deductions on renovations (through the so-called 'ROT-avdrag') are an attempt to decrease the size of the grey sector and encourage official employment. However, such myriad small-scale sites are extremely difficult for both the authorities and the trade unions to access in order to adequately monitor terms and conditions. There is currently a lack of properly researched studies of the impacts of the employment of migrant workers on wage rates and conditions not just in construction but in a range of specific sectors.

Qualitative studies of the living and working conditions of migrant workers in Sweden have only recently begun. Limited available evidence based on individual worker testimony, suggests troubling developments, whereby the collective agreement and the Swedish model of industrial relations increasingly fail to provide effective employment protection. Perhaps typical here is the story of a young Polish worker, Marcin Wilk. He described employment conditions for himself and some seventy fellow workers from Poland and Bulgaria working as seasonal attendants at a private zoo and amusement park in southern Sweden (Aktuellt, 11 December 2012). It was, said Wilk, 'completely a disaster...it's 
feudal...it's from the Middle Ages. It was...a ruler and peasants'. The gross salary received was 12,000 SEK $(€ 1387)$ per month for a six or seven-day working week of ten hours per day, although from seventy hours worked per week, only forty hours or less were paid. No holiday or sick pay was provided. From the gross salary, an additional 3000 SEK (€347) was compulsorily deducted by the employer for accommodation and food. Swedish employees were paid approximately twice as much as foreign workers. Accommodation consisted of twelve-meter square rooms shared between two persons in barrack-like wooden huts on the zoo premises. Concerning the meals supplied, Wilk complained that, 'it was not food but rubbish. It was something like food both for people and for animals.' No written contracts of employment were provided, and although Wilk claimed that he was asked to sign a contract, 'later when I asked about the copy for me I was answered "no, there is no copy for you"' (Wilk correspondence with authors 21 January 2013). Approaches for assistance to a local trade union, the police, the Work Environment Authority and the Discrimination Ombudsman were to no avail. After raising an official complaint with the latter body he was subsequently dismissed. In evidence presented in the Kalmar district court by Wilk in support of a discrimination claim, a zoo management representative, covertly recorded, can be heard to say: 'You think you're better than others. Take your things and go to hell. You're behaving like a damn monkey!' (The Local, 2013a). The case was debarred under a statute of limitation and costs of the proceedings were awarded against Wilk, while a further attempt to appeal this decision at the Labour Court was also rejected. The zoo in question, Ölands djurpark, received national media attention in 2012 following allegations by former employees concerning lack of veterinary care for the animals, irregular feeding, and the alleged clubbing to death of lion cubs purportedly 'surplus' to zoo requirements (SvD Nyheter, 2012). Testimony by this individual worker can be taken together with similar accounts of employment abuse in transcripts of interviews in the LO study previously referred to (Jonsson et al., 2011). Such 
testimony points to growing gaps in the protective coverage provided by the Swedish labour market model. In the next section, it is suggested that these gaps may be further widened by the impact of the introduction of a new employer-led demand-driven 'open' labour migration regime.

\section{The 2008 migration reform}

In 2008, Sweden's centre-right Alliance government with the support of the Green Party, introduced a major reform of the labour migration regime for countries from outside of the EU, EEA and Switzerland (Borevi, 2012: 76-9). Sweden moved from a system that required employers to meet a labour market test, and provided for different entry streams tailored to specific occupations and sectors with different rights and entitlements for different migrant statuses, to a single-stream demand-driven system (Quirico, 2012). This new regime has been characterized as 'the most open in the OECD' (OECD, 2011: 11). It does not impose either skill requirements on migrants or labour market tests, and it is available across all occupations in the Swedish labour market. The reform was designed to create a flexible system that would facilitate the recruitment of workers from third countries in the absence of sufficient domestic labour reserves (Government Bill 2007/08: 147).

Although the EU has taken steps since 1999 to harmonize both the conditions for entry of third country nationals who enter an EU member state in order to work and the rights to which they are entitled to when working within the EU, Member States have been reluctant to abandon their control over immigration (Herzfeld Olsson, 2012). The European Commission initially proposed a directive that limited distinctive treatment between different types of labour migrants to a minimum, which was similar to the scheme that Sweden introduced in 2008 (Herzfeld Olsson, 2012:12). However, when it was obvious that Member States would not agree on such a broad horizontal approach to temporary 
migration for third country nationals, the Commission moved to a piece-meal approach that developed directives for specific groups of migrants such as highly-skilled workers, seasonal workers and intra-company transfers with different levels of employment rights for each group. The emerging legal framework at the EU level would create various tiers of migrant workers with different rights, which is very different than the migration regime currently operating in Sweden. Since directives provide minimum standards and allow Member States a major degree of discretion in how to implement them, the existing Swedish migration regime is not threatened by the proposed EU directives relating to migrant workers.

The new migration regime does, however, impose a set of requirements on employers that are, on the surface, designed to ensure that the terms and conditions of jobs offered to migrant workers do not undermine Swedish labour standards. In addition to minimal advertising requirements (within Sweden and the EU/EEA for at least ten days), employers must establish that the job provides terms and conditions that are comparable to or better than those provided under the relevant collective agreements, or that are customary for that occupation. They also have to demonstrate that the migrant workers will earn sufficient wages (about 13,000 SEK a month or about €1500) to make them ineligible to seek Swedish social assistance. The relevant trade union must be consulted about the terms and conditions of the job offer, although it is up to the Migration Board to decide whether the terms and conditions on offer are acceptable (Migrationsverket, n.d). However, it is important to note that the offer of employment, which establishes the wage rate and benefits for the purposes of immigration approval, is not legally binding.

Work permits link the migrant worker to a specified employer and are issued for a maximum of two years, with the possibility of another two-year extension, during which the 
migrant worker is required to continue to work in the specified occupation but is no longer tied to a specific employer (Migrationsverket, n.d.). The binding nature of the relationship with a specific employer increases migrant workers vulnerability to exploitation. Migrant workers have little recourse, for example, if their employer offers a contract with wages that are significantly less than those set out in the immigration offer. After working for four years in Sweden within a five-year period, the migrant can apply for a permanent residence permit, although approval is not guaranteed. Migrant workers whose employment is terminated are allowed to remain in Sweden a short period, three months, in order to find a new job. On the other hand, all migrant workers are entitled to bring their immediate families, and their spouses are eligible to be granted a work permit.

At the same time as the new one-channel system dramatically cut down the different specialized streams (for seasonal workers and high skilled workers, for example), it also excluded the possibility for some migrant workers to obtain permanent residence status immediately upon entry. Most significantly, by abolishing the labour market shortage test, the role of unions in approval process was diminished. Under the previous regime, applications were sent to the relevant trade union not only for an assessment of wages and working conditions, but also of the labour market situation in the occupation concerned. While not a legal power to 'veto' applications, unions had much greater input into the approval process, and were able 'to block recruitment in firms in which they had little oversight' (OECD, 2011: 126).

In December 2011, OECD published a government-invited review of Sweden's new labour migration policy. The OECD (2011: 86) report notes that between 2005 and 2011 the main countries of origin of work-permit holders were Thailand, India, China, Ukraine, the United States and the Russian Federation. Migrant workers have tended to be channelled into 
different occupations on the basis of their place of origin. In 2011, while migrant agricultural workers were primarily from Thailand, Indian nationals received the majority of permits for computing professionals. Chinese nationals were disproportionately represented in housekeeping and restaurant services work, with Turkish nationals receiving the majority of permits to work as cleaners, and Ukrainian nationals recruited as restaurant helpers. Work permits for some nationals (especially from Vietnam, Mongolia, Iraq, and Bolivia, for example) have increased, leading OECD to speculate that 'ethnic' recruitment networks are being used to fill the low-skilled occupations in restaurants, food processing and personal care that tend to be run by immigrants (OECD, 2011: 88). In 2011 , the largest number of permits, 2821, were issued within the agricultural sector (mainly for Thai seasonal berry pickers), with permits for computer specialists (largely from India) 2795 close behind. Taken together, in 2011, private service occupations, such as housekeeping, cleaning and restaurant work, also accounted for nearly 3000 approved work permits (Migrationsverket, 2011). While the total numbers are relatively small compared to the total working population, the top four low-skilled service occupations (housekeeping and restaurants, cleaners, kitchen and restaurant helpers) saw an increase in work permits granted of about 60\% between 2009 and 2010 (OECD, 2011: 106). The proportion of elementary (or low skilled jobs) rose from $9 \%$ in 2009 to $16 \%$ in 2010 , while the proportion of medium-skilled occupations rose from $26 \%$ to $38 \%$ (OECD, 2011: 106).

\section{Table 1 Work permits granted 2011}

Top 9 occupational groups

Agricultural, fishery and related labourers

Computing professionals

Housekeeping and restaurant services workers

Helpers and cleaners

Helpers in restaurants

Architects, engineers and related professionals

Food processing and related trades workers

Building frame and related trades workers

Physical and engineering science technicians
Number of permits

2821

2795

1323

798

796

630

386

362

338 
Source: Migrationsverket 2011.

In a preliminary assessment of the impact of the reform on wages, OECD (2011: 95-100) compared the average wages of newly recruited resident employees in those firms recruiting labour migrants in 2009, with the average wages of newly recruited resident employees in firms that did not recruit from abroad. After controlling for the characteristics of the workers (age and education) and firms (sector and size), OECD found that the newly recruited resident employees in firms that also recruited from abroad earned on average $10.5 \%$ higher salaries than newly recruited resident employees in firms that did not recruit from outside the EU (OECD, 2011: 97). However, in small firms, which started recruiting only after the reform, the picture was different, with 'significantly lower wages [for resident employees] even after controlling for sector and other characteristics' (OECD, 2011: 98). This finding is troubling since $40 \%$ of the firms recruiting migrant labour in 2009 had fewer than ten employees, and fall within the small firm category (2011: 92). Firm size is linked to union density and collective agreement coverage, with larger firms more likely to be unionized and to adhere to union-negotiated contracts than small firms. As OECD noted, many 'small employers in hotels and restaurants, gardening, agriculture, forestry and subcontracting to local government are outside of collective agreements' (2011: 127).

Union density is also directly related to the capacity of a union to effectively monitor the terms and conditions negotiated in the collective agreement for the sector. Although, as already pointed out, union density is comparatively high in Sweden the recent decline in union membership has most affected those sectors that employ foreign-born workers. From 2006 to 2011, union density in hotels and restaurants fell from $52 \%$ to $33 \%$, a decline of $19 \%$. In 2004, more than one-third of the members of the Hotel and Restaurant Workers' Union were born abroad, while between 2007 and 2008 the union lost one-third of its members. This decline is more than in any other industry, including in construction 
which fell from $81 \%$ to $69 \%$, and in private services sector, which declined from $67 \%$ to $55 \%$ and where here again foreign-born workers are also over-represented among bluecollar workers (Kjellberg, 2012: 11). In fact, the largest shrinkage in union density for workers employed in Sweden was among foreign-born workers (Kjellberg, 2011: 84).

The situation of workers employed in 'home-services' which includes cleaning, gardening and care work, can be equally or even more precarious than it is for migrant workers employed in the restaurant sector. Union density is extremely low for cleaners in public buildings, estimated at between $5 \%$ and $10 \%$, and work-place representatives are very rare (Calleman, 2012). For workers employed as domestic workers in private households there are no collective agreements, which means that for these workers there is no regulation of minimum wages, no rights to worker participation or industrial action, and no automatic access to unemployment benefits (Calleman, 2012: 131). Anti-discrimination legislation applies to the domestic service company, but it does not apply to the relationship between the customer and the household worker. Moreover, the Domestic Work Act provides workers who are employed in private households to perform domestic work with a suite of rights that is not as inclusive or as robust as those provided to other workers. Although there are no official statistics, on the basis of interviews conducted with managers of the two largest domestic services companies, Calleman (2012: 131) found that around $50 \%$ of those employed in this sector were foreign born, mostly from Russia, Estonia, Poland, and Finland. In essence, home-services work is provided mainly by migrant workers, and, if they work in a Swedish home, they are not entitled to many labour-related rights. The Swedish model of autonomous collective bargaining as the mechanisms for standard setting simply does not work for migrant home-service workers. 
Recruitment strategies utilised by employers for different kinds of labour are little understood but appear to be differentiated depending on the type of labour (Petersson 2012). The limited evidence to date suggests that the migration reform is fuelling the recruitment of migrant workers for low-skilled and low-paying jobs for which there is no apparent local labour shortage (OECD, 2011: 131). Tax cuts, introduced in 2007 for purchasers of domestic services, and in 2012 for restaurant visits, were aimed at tackling unemployment by creating regularised jobs through moving those in the informal sector into the formal economy (as with household renovation construction work), and have contributed to the expansion of the private service sector (Gavanas, 2010: 56-73). As noted above, it is to low-paid precarious work in the private service sector (where unions have an increasingly marginal presence) that a large proportion of migrant workers are being recruited. Employers in restaurants, hospitality and personal care, 'who would not have been able to easily use the previous regime, now recruit labour migrants from abroad' (OECD, 2011: 12). OECD notes that the number of employers using the new system more than doubled between 2008 and 2010 and that most of these firms had not used the system previously. Many more recruiters are smaller firms, and many more firms bring in a small number of labour migrants (OECD, 2011: 12). Fears have been raised that some of these companies use the threat of permit loss to extract long hours of work at poor rates of pay and under unsafe conditions. Although the OECD endorsed the new regime, it noted, 'one concern with the introduction of the new system was the potential for abuse by small marginal businesses with no union employees and outside of coverage by collective bargaining agreements' (OECD, 2011: 91). Thus, the OECD recommended that the increase in the number migrants working in low-skilled occupations be monitored (OECD, 2011: 132), which suggests that there is the potential for a growing problem in regulating the terms and conditions of those recruited under the new migration regime. 
This concern, in turn, raises the question of the response of state agencies which is examined in the next section.

\section{Regulating the labour market}

Regulating the restaurant sector provides a concrete example of an area that poses a particular challenge when it comes to the enforcement of minimum labour standards for migrant workers. According to the Hotel and Restaurant Workers' Union (HRF), the Union found several instances of migrant workers in the sector being paid wages that are much lower than the collective agreement (Hotell-och Restaurangfacket, 2011). Moreover, the assumption that small employers, rather than large ones, are more likely to engage in exploitative practices may not be well founded. A group of managers at the McDonald's chain of restaurants are reported as having charged illegal recruitment fees as high as 150,000 SEK $(€ 17,300)$ for each of 24 Pakistani migrant workers placed in a job within the company. Allegations of passport withholding, and of requirements to repay the cost of recruitment fees out of current wages into bank accounts held by relatives of the managers, were being investigated (Aftonbladet, 2012). A further report from the LO trade union confederation suggests that at least half of the workers with two-year work permits may have paid for them (The Local, 2013b).

The Work Environment Authority (Arbetsmiljöverket), which has regulatory oversight of health and safety as well as working time, has singled out restaurants as employers of migrant workers for special scrutiny. It provides information on working standards, in a range of languages, including Arabic, Thai, Bengali, Hindi, Chinese, Turkish, and Urdu (Arbetsmiljöverket, nd). It advises migrant workers who suspect that their working conditions are either dangerous or not consistent with laws and regulations, to, 'in the first instance, speak to [their] employer' before mentioning that they can turn to the Safety 
Officer at their workplace or to the Authority (Arbetsmiljöverket, nd). This advice is problematic given the fact that migrant workers' immigration status is dependent upon an on-going employment relationship with the employer who obtained the work permit for them, and it is not uncommon for employers to retaliate against employees who complain about violations of labour standards. Moreover, the remit of the Authority does not extend beyond health and safety and working time to contractual matters of wages, this being the province of the collective agreement. At the same time its resources have been subject to major retrenchment during the lifetime of the current administration, with staffing levels cut by one third.

A key weakness that OECD identified in its review of the Swedish temporary migration system, is the absence, other than at renewal, of any 'formal post-arrival verification mechanism' that ensures employers are complying with labour standards (OECD, 2011: 126). This criticism is vociferously echoed by trade unions. Moreover, in its 2011 final report, the Government Committee of Inquiry on Circular Migration and Development, found that 'there are cases where dubious or criminal employers take advantage of or cheat employees. Employers that do not respect laws and working conditions are a problem not only for their employees but for the labour market as a whole' (Statens Offentliga Utredningar, 2011: 131). In this context, repeated accounts of dire conditions and low rates of pay for third country migrants (The Local, 2013c; DN.se, 2013a, 2013b), as well as poor conditions for Central and East European workers, in sectors such as cleaning, horticulture and hospitality have emerged over recent years. Such reports lend credence to OECD warnings, and have succeeded in provoking leading trade unions in these sectors to proclaim jointly 'Now enough is enough!' (SVD Opinion, 2011). 
At a public policy level there appears to be a new recognition of the broad challenges to the Swedish model posed by posting and by the current migration regime. Perennial concerns have been raised over the poor conditions of migrant seasonal berry-pickers and in response the Swedish government has introduced a raft of sector-specific employer controls (Woolfson et al., 2012). In January 2012, the Migration Board introduced new general regulations, modelled on the berry-picker labour control initiatives, to screen and follow-up on employers in sectors considered to run a higher risk for abuse of the open system. Cleaning, hospitality, agriculture, car mechanics, retail, service and temporary work agencies were targeted, as were all businesses (regardless of sector) that had operated for less than one year before the application. Apart from the general requirements regarding wages and working conditions, new employers and employers in the specified sectors have to show how they can guarantee the migrant workers' salary for at least three months. In addition, if employers have previously employed migrant workers from outside of the EU, they must provide the Migration Board with tax statements regarding the migrant workers' wages for the last three months. Companies operating within the specified sector and registered in a country outside the EU must have a branch registered in Sweden (Migrationsverket, n.d.). However, at the same time as the Migration Board imposed controls on employers in specified sectors who are seeking migrant workers, the Board made it easier and faster for employers who make at least 25 applications for permits per year and operate a business registered in Sweden to obtain approval for hiring migrant workers by providing a certification system (Migrationsverket, 2012).

It is still too soon to assess the impact of the new control measures. In theory, they should mitigate the risk that migrant workers are recruited by shady employers who sell work permits and exploit the migrant workers' dependency. However, these new measures, 
while they have led to more rejections of employer applications for permits, appear not to have slowed down the recruitment of migrant workers overall $(16,543$ work permits issued in 2012) (Migrationsverket, 2013). As in previous years, the largest single group of permits was for seasonal Thai berry pickers (5784). Moreover, about half of the total of permits granted (8500) were for unskilled 'elementary occupations' and 'service workers and shop sales workers' in the poorly organized private sector, rather than for managerial, higher level computer specialists or even skilled manual jobs (Migrationsverket, 2013).

In a similar vein, the Work Environment Authority has indicated the need for oversight in workplaces that employ migrant workers, particularly in the so-called 'grey sector' of the economy (Arbetsmiljöverket, 2012). At this point in time, the Work Environment Authority has neither the powers nor the resources to deal with the range of irregular contractual practices to which migrant workers are subjected, especially through increasingly long and complex chains of subcontracting and the use of 'self-employed' contractors. It has therefore proposed strengthening the liabilities for the main contractor in relation to subcontracting, especially in complex public procurement contracts. This suggestion conforms to the main thrust of a new EU Enforcement Directive for posted workers which attempts to address the vocal concerns of the European trade unions concerning the postLaval posting arrangements, by seeking to encourage joint and several liability among contractors to guard against non-payment of wages and other abuses (European Commission, 2012: 18ff). The Authority has also, more controversially, suggested a new workplace inspectorate, which would inspect workplaces with foreign workers in order to address wages and conditions of workers who are not members of any trade union. In addition, it has proposed more co-ordinated inter-agency information-sharing and the introduction of identity cards, similar to those which exist for foreign construction workers in Norway and Iceland, seen both as an effective control measure of undeclared labour at site level and as a means of enhancing health and safety. In line with the forthcoming 
directive, the Work Environment Authority will act as a liaison office or information point on Swedish employment terms and conditions for foreign companies seeking to deploy labour in Sweden.

In September 2012 the Swedish government appointed a parliamentary committee of inquiry, reporting in December 2014, with the task of investigating the scale and nature of posting arrangements, the conditions for workers who are posted to and working in Sweden, and the possible legislative changes necessary in order to protect the Swedish model (See Dir. 2012:92; Regeringskansliet, 2012). In establishing the terms of reference of the committee, the Ministry of Labour, under whose auspices the inquiry is proceeding, has conceded the trade union view that currently 'only a few collective terms have been submitted to the Work Environment Authority' (Dir. 2012:92: 2).

Trade union confederations in Sweden have been divided over the 2008 reform of the migration regime. The LO, which has seen the highest reduction in membership in its affiliates, wants the labour market needs test reintroduced, as well as greater monitoring of migrant workers' wages and conditions of employment (Lundby Wedin et al., 2010). It fears that employers in less well organized areas of the private sector such as restaurant and hospitality simply avoid paying collective agreement terms and conditions. The McDonald's case discussed above has been further grist to the LO's mill, but it has also documented many other instances of wage dumping. With respect to concerns raised over posting, the Building Workers' Union Byggnads threatened an unprecedented week of strike action in March 2013, involving 3000 employees across 160 different worksites. Reviving an old trade union slogan 'ordning och reda på arbetsmarknaden' ('order and method in the labour market'), the union's stated aim was to pressure building employers to accept that as part of a future collective agreement, prime contractors as in Norway, 
should take responsibility for ensuring that all sub-contractors in the chain abide by the industry agreement. As the union itself rather quaintly put it, embarking on industrial confrontation was rather like 'swearing in church', but it would appear that a 'tipping point' had been reached (Arbetets Marknad, 2013).

By contrast, the white-collar trade union confederation TCO, while sharing LO's concerns over posting and the erosion of collectively bargained terms and conditions, has embraced the change in the migration regime introduced in 2008; its affiliates are deeply embedded in the sectors in which skilled migrant workers, such as information technologists (the second largest occupational group of migrants admitted under the new migration regime) are recruited (Confederation for Professional Employees TCO, 2012). In this regard the picture in Sweden is thus more complex and possibly more fluid than studies of other older member states in terms of union responses to migration would seem to suggest (Fitzgerald and Hardy, 2010; Meardi, 2012; Marino, 2012; Eldring et al., 2012; Hardy et al., 2013).

\section{Conclusion}

The 2008 changes in the Swedish migration regime coincided with the downturn in demand as a result of the global financial and economic crisis. Despite the supposed openness of the new regime the number of work permits granted has remained stable between 2008 (around 14,500) and in 2011 (14,722), with a slight upturn in $2012(16,543)$. The timing of the change in the migration regime - coinciding with the global economic crisis - rather than the openness of the system may explain the modest impact it has had so far, in terms of its overall intention to provide employers with a fast track for (skilled) labour recruitment. Four years after the new regime had been introduced, less than 60,000 permits in total had been granted. Migration Board statistics showed that 40,000 of those 
recruited through this channel had already departed from Sweden, and only 20,500 permits were still in use as of January 1, 2013 (Migrationsverket, 2013). These figures can be read in two ways. The Confederation of Swedish Enterprise, Svenskt Näringsliv (2013), has argued that the overall objectives of temporary 'circular' migration are being achieved and skill shortages are being effectively addressed through the new regime. That said, however, the number of computer specialists recruited from third countries, at around 3000 per year, has remained relatively constant and rather modest.

An alternative reading would suggest that the majority of employers have taken advantage of the new system to recruit other categories of labour. Moreover, it appears they have largely sought to avoid offering a permanent position to temporary employees, or the employees themselves have chosen to quit after the expiry of the two year period during which residence permission is tied to a specific employment offer. Only about $15 \%$ of those who were granted work permits in 2009 had residence permits two years later (Pelling and Karlsson, 2012). This suggests that recruitment of new batches of insecure and precarious replacement workers and the creation of a cheap disposable migrantbased labour force as a preferred employer option. If, and when, the general economic recovery eventually resumes, intensified recruitment, paradoxically, may provide new momentum for an increasing bifurcation of migrant streams in what appears as an 'open' migration regime (Ekberg, 2011; OECD, 2011: 88). Sweden's shift from its previous social democratic model towards a more pronounced neo-liberal configuration provides a marketled underpinning for such developments to be consolidated.

The implications of the Laval judgment and the Lex Laval law continue to dominate the agenda of the trade unions. The ILO's influential Committee of Experts on the Application of Conventions and Recommendations (CEACR) has observed that the limitations imposed by Lex Laval on Swedish trade unions' right to take industrial action in order to 
persuade a foreign employer posting workers to Sweden to sign a collective agreement, are in violation of core ILO Conventions of freedom of association (87) and rights to collective bargaining (98) (ILO, 2013:179). The ILO requested the Swedish government to review the legislation so as to ensure that unions 'are not restricted in their rights simply because of the [foreign] nationality of the enterprise' (ILO, 2013:179). Moreover, the Committee of Experts was concerned that the building workers' and electricians' unions were obliged by the Swedish Labour Court to pay damages as a result of their industrial action, despite the fact that the strike action was lawful under Swedish law in effect at that time. The Committee requested the government review this matter and compensate the two unions (ILO, 2013: 178).

Perhaps most pertinent for the argument presented here, the Committee further acknowledged that legislative restriction on industrial action has hampered the building workers' union in its attempt to achieve collective agreements (ILO, 2013: 179). It noted statistics from the Swedish National Mediation Office that showed a drop in the number of industrial disputes involving foreign employers after the Laval decision, a decline which continued after Lex Laval was enacted (ILO, 2013: 178). Since industrial action has traditionally been the primary means for persuading employers to enter into collective agreements, it is not surprising that the number of collective agreements directly concluded with foreign employers dropped significantly: from 107 in 2007 to 33 in 2011 , (although, through membership in an employer's organization, an additional five foreign employers were bound to the collective agreement) (ILO, 2013: 179). In effect, unions can only request, but not threaten sanctions in order to obtain collective agreements with companies from other EU member states or third countries posting workers in Sweden (LO and TCO 2010). In such cases, according to the trade unions, the current legal framework creates 'collective agreement-free zones' on the labour market 'where it is only possible to 
conclude a collective agreement if the employer accepts it voluntarily' (European Committee of Social Rights, 2012: 22). The Committee of Experts appears to support the trade union contention that the Swedish model of autonomous collective bargaining is being legislatively undermined (ILO, 2013). The Committee's observations may increase moral suasion on the Swedish government in its ongoing review of posting arrangements, and, perhaps, lead it to restore some measure of trade union control in national terms, while simultaneously reaffirming Sweden's international reputation for taking a leading position in upholding international conventions.

A key challenge will remain however. Even with future legislative reform, in the absence of an inclusive trade union strategy towards migrant workers, in sectors outside of the coverage of the collective agreement, migrant workers will remain vulnerable to labour market exploitation and precariousness. This is a danger that, to be fair, the trade unions themselves recognise in devising appropriate organisational responses to prevent the consolidation of an ethnic or 'racialized' secondary labour market (LO, 2012b). Failure here would mean that those performing 'the jobs that Swedes don't want to do' under inferior terms and conditions will be beyond the protective reach of the remaining Swedish model. In this emergent segmented labour market, gravitational effects may tend towards a continuous erosion of labour standards rather than a generalised 'race to the bottom'.

\section{Acknowledgements}

The authors gratefully acknowledge the support of FAS (Swedish Council for Working Life and Social Research) grant to REMESO as a designated centre of excellence and FAS Project: 2011-0338, East-West labour migration, industrial relations and labour standards in a Swedish-Baltic context as well as the Swedish Institute Visby programme grant 
00749/2010. Petra Herzfeld Olsson, Jens Arnholtz, Alessandra Asteriti, Stefania Marino and anonymous reviewers provided valuable comments on various drafts of this article. Any errors and omissions remain those of the authors.

\section{REFERENCES}

Aftonbladet (2012) Sålde jobb på McDonalds - för 100000 kr. 2 december 2012. Available at: http://www.aftonbladet.se/nyheter/article15867932.ab (accessed 9 December 2012).

Aktuellt SVT2 (2012) Gästarbetare utnyttjas [Guestworker abuse]. 11 December.

Andersson M and Thörnqvist C (2007) Determining Wages in Europe's SMEs. How Relevant are the Trade Unions? Transfer: European Review of Labour and Research 13(1): 55-73.

Anxo, D and Niklasson H (2006) The Swedish Model in Turbulent Times: Decline or Renaissance? International Labour Review 145 (4): 339-371.

Arbetets Marknad (2013) Ropen skalla, kollektivavtal till alla! 4 Mars. Available at: http://arbetetsmarknad.se/ledare/varsel-om-konflikt-kollektivavtal-tillalla/?utm_campaign=cmp_184650\&utm_source=getanewsletter (accessed 8 March 2013).

Arbetsmiljöverket (Work Environment Authority) (nd) A safer restaurant for everyone! Available at: http://www.safeatwork.se/restaurant/ (accessed 8 December 2012). Arbetsmiljöverket (Work Environment Authority (nd) A good working environment at your restaurant! Available at: http://www.safeatwork.se/restaurant/files/2012/11/611_English.pdf (accessed 9 December 2012).

Arbetsmiljöverket (Work Environment Authority) (2012) Förstudie om det fortsatta arbetet med utländska företag och arbetstagare. Rapport 2012: 5. Available at: 
http://www.av.se/dokument/publikationer/rapporter/rap2012_05.pdf (accessed 9 December 2012),

Ashiagbor D (2009) Collective Labor Rights and the European Social Model. Law and Ethics of Human Rights 3(2): 221-266.

Asteriti A (2012) Laval and the myth of social dialogue. European Journal of Legal Studies, (forthcoming).

Borevi K (2012) Sweden: The flagship of multiculturalism. In: Brochman G and Hagelund A eds. Immigration Policy and the Scandinavian Welfare State 1945-2010. London: Palgrave Macmillan.

Bosch G (2012) Transnational labour markets and national wage setting systems in the EU. Paper to ILERA $16^{\text {th }}$ World Congress, Philadelphia. Available at: http://ilera2012.wharton.upenn.edu/RefereedPapers/BoschGerhard\%20ILERA.pdf (accessed 3 November 2012).

Calleman C (2011) Domestic Services in a Land of Equality: The Case of Sweden. Canadian Journal of Women and the Law 23(1): 121-139.

Confederation for Professional Employees (TCO) (2012) Bättre kontroll för bibehållen öppenhet - så kan reglerna för arbetskraftsinvandring förbättras. Available at: http://tco.se/3aac1126-1107-40f8-b510-d929426cbe7d.fodoc (accessed 18 August 2012).

Dahlkvist I, Färnbo M, and Waltersson Y (2010) Skattefusk och utnyttjade arbetare i statens miljardprojekt. Dagens Arena, 12 juli 2010. Available at: http://www.dagensarena.se/innehall/skattefusk-och-utnyttjade-arbetare-i-statensmiljardprojekt/ (accessed 20 December 2012).

Davesne A (2009) The Laval Case and the Future of Labour Relations in Sweden. Les cahiers Européens No. 01, Février, Paris: Sciences Po. 
Dir. 2012:92 (2012) Kommittédirektiv, Utstationering på svensk arbetsmarknad, Beslut vid regeringssammanträde den 27 september 2012. Available at: http://regeringen.se/content/1/c6/20/03/91/64788f4b.pdf (accessed 9 December 2012).

DN.se (2013a) Alliansens jobbreform slog snett, 29 January. Available at: http://www.dn.se/ekonomi/bara-ett-av-tre-arbetstillstand-gar-till-specialister (accessed 4March2013).

DN.se (2013b) Papperslöse Deniz utnyttjades av arbetsgivaren, 29 January. Available at: http://www.dn.se/ekonomi/papperslose-deniz-utnyttjades-av-arbetsgivaren (accessed 4 March2013).

Dølvik J-E and Visser J (2009) Free Movement, Equal Treatment and Workers' Rights:

Can the European Union Solve Its Trilemma of Fundamental Principles? Industrial Relations Journal 40(6): 491-509.

Economist, The (2012) Sweden: The New Model. 13 October. Available at: http://www.economist.com/node/21564412 (accessed 10 March 2013)

Economist, The (2013) Special Report .The Nordic Countries. Available at: http://www.economist.com/news/special-report/21570840-nordic-countries-arereinventing-their-model-capitalism-says-adrian (accessed 22 March 2013).

Eironline (2010) Sweden: Posted workers. Dublin: Eurofound, 16 October. Available at: http://www.eurofound.europa.eu/eiro/studies/tn0908038s/se0908039q.htm (accessed 18 November 2012).

Ekberg J (2011) European versus non-European immigrants on the Swedish labour market during the recession. CAFO Working Papers, No. 2, Centre for Labour Market Policy Research (CAFO), School of Business and Economics, Linnaeus University. Available at: http://www.snee.org/filer/papers/628.pdf (accessed 19 November 2012). 
Eklund R (2006) The Laval case. Industrial Law Journal 35(2): 202-208.

Eldring L, Fitzgerald I and Arnholtz J (2012) Post-accession migration in construction and trade union responses in Denmark, Norway and the UK. European Journal of Industrial Relations 18(1): 21-36.

Engblom S (2012) Labour Migration, Trade in Services, Equal treatment, and the Role of the EU. In: Karlsson J O and Pelling L (eds) Moving Beyond Demographics Perspectives for a Common European Migration Policy. Stockholm: Global Utmaning.

ETUC (2007) Laval (Vaxholm) case. European Trades Union Council. Available at: http://www.etuc.org/r/847 (accessed 19 November 2012).

European Commission (2012) Proposal for a Directive of the European Parliament and of the Council on the enforcement of Directive 96/71/EC concerning the posting of workers in the framework of the provision of services. Brussels, 21.3.2012, $\operatorname{COM}(2012) 131$ final, 2012/0061 (COD). Available at:

http://ec.europa.eu/commission_20102014/andor/headlines/news/2012/03/20120321_en.htm (accessed 22 November 2012).

European Committee of Social Rights (2012) Swedish Trade Union Confederation (LO) and Swedish Confederation of Professional Employees (TCO) v. Sweden Complaint No. 85/2012, Case No.1. 12 July, Council of Europe. Available at: http://www.coe.int/T/DGHL/Monitoring/SocialCharter/Complaints/CC85CaseDoc1_e n.pdf (accessed 2 March 2013).

Färnbo M (2010) SvD skriver om Dagens Arenas avslöjande. Dagens Arena, 21 december 2010. Available at: http://www.dagensarena.se/redaktionen/svd-skriver-om-dagensarenas-avslojande/ (accessed 20 December 2012). 
Fitzgerald I and Hardy J (2010) 'Thinking Outside the Box'? Trade Union Organizing Strategies and Polish Migrant Workers in the United Kingdom. British Journal of Industrial Relations 48(1): 131-150.

Fudge J (2011) Constitutionalizing Labour Rights in Europe. In: Campbell T Ewing K and

Tompkins A (eds) The Legal Protection of Human Rights: Sceptical Essays.

Oxford: Oxford University Press, pp. 244-67.

Gavanas A (2010) Who cleans the welfare state? Migration, informalization, social

exclusion and domestic services in Stockholm. Institute for Futures Studies:

Research Report 2010/3.

Government Bill 2007/08: 147, Nya regler för arbetskratsinvandring, 1.

Government Bill 2009/10: 48, Åtgärder med anledning av Lavaldomen.

Hardy J, Eldring L and Schulten T (2013) Trade union responses to migrant workers from the 'new Europe': A three sector comparison in the UK, Norway and Germany. European Journal of Industrial Relations (forthcoming).

Herzfeld Olsson P (2012) Giving to those who have and taking from those who have not:

The

development of an EU policy on workers from third countries. Formula Working Paper no. 34, University of Oslo. Available at:

http://www.jus.uio.no/ifp/english/research/projects/freemov/publications/presentatio ns/2012/Olsson.pdf (accessed 25 July 2013).

Hotell- och Restaurangfacket, (Hotel and Restaurant Workers' Union HRF) (2011) Migrationsprojektet slutrapport 2011. Available at: http://www.hrf.net/node/218 (accessed 18 August 2012).

ILO (2013) Observation (CEACR) - adopted 2012, published 102nd ILC session (2013) Freedom of Association and Protection of the Right to Organise Convention, 1948 (No. 87) - Sweden (Ratification: 1949) Available at: 
http://www.ilo.org/dyn/normlex/en/f?p=1000:13100:0::NO::P13100_COMMENT_ID: 3085286 (accessed 2 March 2013).

Jonsson C-M, Pettersson T, Lofgren H and Arvidsson K (2011) When Labour Costs Squeeze the Price - An Analysis of Public Sector Investments in Infrastructure. LO and BSLN, Stockholm. Available at:

http://www.bslabour.net/images/stories/Labour_markets/report\%20lo\%20infrastruct urproject\%20english\%20version.pdf (accessed 30 October 2011).

Kilpatrick C (2011) Internal Market Architecture and the Accommodation of Labour Rights: As Good as it Gets? EUROPEAN UnIVERSITY INSTITUTE WORKING PAPERS LAW, 2011/04.

Kjellberg A (2011) The Decline in Swedish Union Density since 2007. Nordic Journal of Working Life Studies 1(1): 67-93.

Kjellberg A (2012) Kollektivavtalens täckningsgrad samt organisationsgraden hos arbetsgivar-förbund och fackförbund. Studies in Social Policy, Industrial Relations, Working Life and Mobility, Research Reports 2010:1, (updated 2 October 2012), Lund University. Available at:

http://lup.lub.lu.se/luur/download?func=downloadFile\&recordOld=1545448\&fileOld= 1545800 (accessed 21 March 2013).

Krings T (2009) 'A Race to the Bottom?' Trade Unions, EU Enlargement and the Free Movement of Labour. European Journal of Industrial Relations 15(1): 49-69.

Krings T, Bobek A, Moriarty E, Salamon J and Wickham J (2011) From boom to bust: Migrant labour and employers in the Irish construction sector. Economic and Industrial Democracy 32(3): 459-476.

Lindstrom N (2010) Service Liberalization in the Enlarged EU: A Race to the Bottom or the Emergence of Transnational Political Conflict? Journal of Common Market Studies 48(5): 1307-1327. 
LO (Swedish Trade Union Confederation) (2012a) Facklig anslutning år 2012. Facklig anslutning bland anställda efter klass och kön år 1990-2012. LO: Stockholm. Available at:

http://www.lo.se/home/lo/home.nsf/0/D966DD2C17BE7D61C1257AD100312128/\$fi le/Facklig_anslutning_2012.pdf (accessed 14 May 2013).

LO (Swedish Trade Union Confederation) (2012b) Sökes: Kompetent, flexibel och billig arbetskraft - hur arbetsgivarnas krav ökar polariseringen på arbetsmarknaden.

Delrapport 1: Arbetsmarknaden efter krisen. Available at:

http://mb.cision.com/Public/706/9335865/8c6f7122a6162adc.pdf (accessed 22 November).

LO (Swedish Trade Union Confederation) and TCO (Confederation of Professional Employees) (2010) Comments by LO and TCO to the CEACR on Sweden's application of C. 87 and 98, 31 August 2010. Available at: www.tco.se/5f1bb1e1aa81-4e1e-96ec-136bff182c6d.fodoc (accessed 2 March 2013).

Local, The (2013a) Pole loses discrimination fight against Swedish zoo, 21 January. Available at: http://www.thelocal.se/45732/20130121/ (accessed 2 March 2013).

Local, The (2013b) Most work permits given to low-skilled workers, 29 January. Available at: http://www.thelocal.se/45880/20130129/\#.UTBFwx2cdvA (accessed 7 March 2013).

Local, The (2013c) Swedish forestry firms in migrant labour scandal, 23 January. Available at: http://m.thelocal.se/45768/20130123/ (accessed 2 March 2013).

Lundby Wedin W (2010) Stoppa rovdriften på arbetskraft. Svenska Dagbladet, 21 November 2010. Available at: http://www.svd.se/opinion/brannpunkt/stopparovdriften-pa-arbetskraft_5703123.svd (accessed 18 August 2012). 
MacKenzie R, Forde C, Robinson A, Cook H, Eriksson B, Larsson P and Bergman A (2010) Contingent work in the UK and Sweden: evidence from the construction industry. Industrial Relations Journal 41(6): 603-21.

Malmberg J (2010) Posting Post Laval International and National Responses. Uppsala Center for Labor Studies, Department of Economics, Working Paper 2010:5.

Marino S (2012) Trade union inclusion of migrant and ethnic minority workers: Comparing Italy and the Netherlands. European Journal of Industrial Relations 18(1): 5-20. Meardi G (2012) Union Immobility? Trade Unions and the Freedoms of Movement in the Enlarged EU. British Journal of Industrial Relations 50(1): 99-120.

Migrationsverket (Migration Board) (nd) Opinion from relevant union. Available at: http://www.migrationsverket.se/download/18.478d06a31358f988845800023309/Fac kligt_yttrande.pdf (accessed 10 December 2012).

Migrationsverket (Migration Board) (2011) Work Permits Granted 2011. Available at: http://www.migrationsverket.se/download/18.46b604a812cbcdd7dba800027742/Be viljade+arbetstillstånd+2011+-+Work+permits+granted+2011.pdf (accessed 19 August 2012).

Migrationsverket (Migration Board) (2012) Stricter requirements for work permits have the desired effect. Available at: http://www.migrationsverket.se/info/6180_en.html (accessed 7 March 2013).

Migrationsverket (Migration Board) (2013) Work Permits Granted 2012. Available at: http://www.migrationsverket.se/download/18.43648b4513b902d42692f5e/Beviljade +arbetstillst\%C3\%A5nd+2012+-+Work+permits+granted+2012.pdf (accessed 7 March 2013).

OECD (2011) Recruiting Immigrant Workers, Sweden. Paris: OECD Publishing. 
Pelling L and Karlsson JO (2012) Därför bör utländska arbetare ges permanenta uppehållstillstånd. Available at: http://www.newsmill.se/artikel/2011/11/29/d-rf-r-b-rutl-ndska-arbetare-ges-permanenta-uppeh-Ilstillst-nd (accessed 18 August 2012).

Petersson S (2012) Bemanningsföretagens roll i rekryteringen av utländsk arbetskraft, Stockholms universitets Linnécentrum för integrationsstudier (SULCIS) Rapport 2012:1.

Quirico M (2012) Labour migration governance in contemporary Europe. The case of Sweden. FIERI - Forum Internazionale ed Europeo Di Richereche sull'Immigrazione, Working Papers, April. Available at: http://www.labmiggov.eu/wpcontent/uploads/2012/04/CASE-STUDY-SWEDEN-FINAL-REPORT1.pdf (accessed 23 November 2012).

Regeringskansliet (2012) Ny parlamentarisk kommitté ska se över reglerna om utstationering på svensk arbetsmarknad. Pressmeddelande. 1 oktober 2012, Arbetsmarknadsdepartementet. Available at:

http://regeringen.se/sb/d/16311/a/200510 (accessed 9 December 2012).

Schierup C-U and Ålund A (2011) The end of Swedish exceptionalism? Citizenship, neoliberalism and the politics of exclusion. Race \& Class 53(1): 45-64.

Schulten T (2006) Statutory and collectively agreed minimum wages in Europe - an international overview. In: Schulten T Bispinck R and Schäfer C Minimum Wages in Europe. Brussels: ETUC-REHS, pp.1-24.

Schwab K (ed) (2012) Insight Report. The Global Competitiveness Report 2012-2013. Full Data Edition. Geneva: World Economic Forum. Available at: http://www3.weforum.org/docs/WEF_GlobalCompetitivenessReport_2012-13.pdf (accessed 25 December 2012).

Statens Offentliga Utredningar (2011) Cirkulär migration och utveckling - förslag och framåtblick (SOU 2011: 28). 
SvD Nyheter, Hård kritik mot Ölands djurpark, 16 oktober 2012 kl 06:44, uppdaterad: 17 oktober 2012 kl 14:55. Available at: http://www.svd.se/nyheter/inrikes/hard-kritikmot-olands-djurpark_7585110.svd (accessed 12 December 2012).

SvD Opinion, Vidrigt utnyttjande måste stoppas, 17 juli 2011 kl 04:45, uppdaterad: 18 juli 2011 kl 15:53. Available at: http://www.svd.se/opinion/brannpunkt/vidrigtutnyttjande-maste-stoppas_6325490.svd (accessed 12 December 2012).

Svenskt Näringsliv (Confederation of Swedish Enterprise) (2013) Successful immigration reform attracts experts to Sweden, 22 February. Available at: http://www.svensktnaringsliv.se/english/successful-immigration-reform-attractsexperts-to-sweden_183710.html (accessed 7 March 2013).

Thörnquist A (2011) False self-employment: a topical but old labour market problem. In: Thörnquist A and Engstrand Å.-K (eds) Precarious Employment in Perspective: Old and New Challenges to Working Conditions in Sweden. Bruxelles, Bern, Berlin, Frankfurt am Main, New York, Oxford, Wien: Peter Lang, pp.101-29.

Thörnqvist C (2011) The most powerful industrial relations system in the world? Pros and cons of the Swedish collective bargaining system in the light of the Laval conflict. In Thörnquist A and Engstrand $\AA-K$ (eds) Precarious Employment in Perspective: Old and New Challenges to Working Conditions in Sweden. Bruxelles, Bern, Berlin, Frankfurt am Main, New York, Oxford, Wien: Peter Lang, pp. 23-45.

Woolfson C Thörnqvist C and Sommers J (2010) The Swedish model and the future of labour standards after Laval. Industrial Relations Journal, 41(4): 333-350.

Woolfson C Herzfeld Olsson P and Thörnqvist C (2012) Forced Labour and Migrant Berry Pickers in Sweden. International Journal of Comparative Labour Law and Industrial Relations, 28(2): 147-176.

Wright CF (2012) Immigration policy and market institutions in liberal market economies. Industrial Relations Journal 43(2): 110-136. 
Charles Woolfson is Professor of Labour Studies at REMESO, the Institute for Research on Migration, Ethnicity and Society, Linköping University. His research is on labour and migration from the newer EU member states. With Jeffrey Sommers he is joint editor of The Contradictions of Austerity: The Socio-Economic Costs of the Neoliberal Baltic Model. London and New York: Routledge, 2014).

Judy Fudge is Professor at Kent Law School, the University of Kent, UK. She has published on employment and labour law, feminist political economy and migrant workers. Her most recent edited publication with Kendra Strauss is Temporary work, agencies, and unfree labour: Insecurity in the new world of work (London and New York: Routledge, 2013).

Christer Thörnqvist is an Associate Professor and an affiliated researcher at REMESO. His main research interest is in the development of the Swedish industrial relations model and labour migration. He has published in the European Journal of Industrial Relations, Industrial Relations Journal, International Journal of Comparative Labour Law and Industrial Relations. 